\section{Evaluation of some microbiological and chemical parameters of Campania buffalo ricotta cheese}

\author{
Angela M.I. Montone, ${ }^{1}$ \\ Alessandra De Felice, ${ }^{1}$ \\ Roberta Brunetti, ${ }^{1}$ Domenico Mollica, ${ }^{2}$ \\ Salvatore Capo, ${ }^{1}$ Federico Capuano, ${ }^{1}$ \\ Achille Guarino, ${ }^{1}$ Donatella Nava ${ }^{1}$ \\ ${ }^{1}$ Department of Food Inspection, \\ Institute for Experimental Veterinary \\ Medicine of Southern Italy, Portici
}

(NA); ${ }^{2}$ Local Health Unit NA3 Sud U.O.

Vet. 59 Penisola Sorrentina, Italy

\begin{abstract}
Fresh ricotta (whey cheese), owing to its technological characteristics and intrinsic parameters $\left(\mathrm{pH}\right.$ and $\mathrm{a}_{\mathrm{w}}$ ), is an excellent substrate for the growth of spoilage and pathogenic microorganisms. On 19 July 2010, Campania buffalo ricotta cheese was assigned to the register of Protected Designations of Origin (PDO) by the European Commission, with EC Reg. $634 / 2010$. It is mainly produced in the provinces of Caserta and Salerno around the rivers Garigliano and Volturno, the plain of the river Sele and the area of Cilento. This article reports the results of a 9-month monitoring (from May 2014 to January 2015) of ricotta samples aiming at evaluate the microbial status of some cheese factories, since ricotta is considered particularly suitable to judge the hygienic level of the dairy establishments. Four dairies were selected for sampling according to their different structural characteristics and the
\end{abstract}

adequacy of both their premises and equipment.

\section{Introduction}

Ricotta has very ancient origins and is highly appreciated owing to its nutritional values and low cost. It is obtained from the whey which is steam-heated up to a temperature of about $82^{\circ} \mathrm{C}$ and then to $92^{\circ} \mathrm{C}$ (the Latin term recoctus means cooked twice). Heating causes the albumin and lactalbumin denaturation and aggregation. The addition of both cizza, i.e. lactic acid or citric acid, and buffalo milk and/or fresh cream are allowed in order to enhance the process of coagulation of the whey proteins, obtain a more compact structure and increase the yield, respectively. Differences in structure are determined by the $\mathrm{pH}$ value at which heat treatment takes place and by the different ratios of $\beta$-Lg and $\alpha$-La. In buffalo ricotta, the ratio of $\beta-\mathrm{Lg}$ to $\alpha-\mathrm{La}$ is $80: 20$; at the moment of the thermo coagulation the $\mathrm{pH}$ value of the serum is 6.26 (Addeo and Coppola, 1983). Because of the high temperatures reached during production, fresh ricotta is naturally poor in competitive microflora (Pintado et al., 2002). However, spores that survive at high temperatures, as those of Bacillus cereus, may be detected (De Santis et al., 1999). The microbiological status of the ricotta may be useful to evaluate the hygiene of the production chain, owing to the open nature of the production, which includes handling of the curd after floating (Greenwood et al., 1991). Moreover, considering the ricotta limited shelf-life, it is essential to ascertain the microbiological characteristics of the buffalo ricotta cheese in order to assess the risk for the consumer.
Correspondence: Donatella Nava, Institute for Experimental Veterinary Medicine of Southern Italy, Via Salute 2, 80055 Portici (NA), Italy

Tel. +39.0817865338 - Fax: +39.0817865342 .

E-mail: donatella.nava@cert.izsmportici.it

Key words: Campania buffalo ricotta cheese; Monitoring; Pseudomonas; Total mesophilic bacteria

Conflict of interest: the authors declare no potential conflict of interest.

Received for publication: 29 September 2016. Revision received: 19 July 2017.

Accepted for publication: 24 July 2017.

This work is licensed under a Creative Commons Attribution-NonCommercial 4.0 International License (CC BY-NC 4.0).

(C) Copyright A.M.I. Montone et al., 2017 Licensee PAGEPress, Italy

Italian Journal of Food Safety 2017; 6:6316 doi:10.4081/ijfs.2017.6316

\section{Materials and Methods}

For the present study, four dairies were selected on the basis of the authorization for Protected Designations of Origin (PDO); the level of implementation of Good Manufacturing Practices (GMP) and the hygienic adequacy of the working area and the equipment. Two samples each month were collected in the selected dairies from May 2014 to January 2015. All samples $(n=72)$ were transported, in their primary packaging and under refrigeration conditions $\left(4 \pm 1^{\circ} \mathrm{C}\right)$, to the laboratory, where they were immediately analyzed for the detection of the following microbiological parameters: Salmonella spp. (AFNOR BRD 07/6-07/04); Listeria

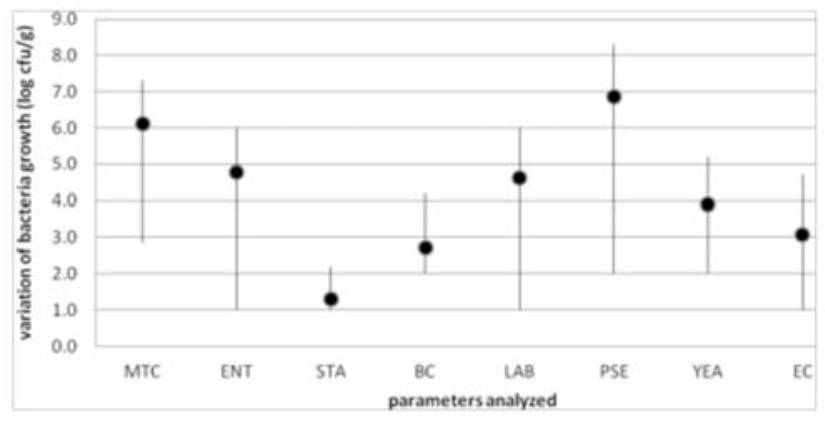

Figure 1. Average, maximum and minimum logarithmic values of the parameters tested. MTC: mesophilic total content; ENT: Enterobacteriaceae; STA: Staphylococci; BC: Bacillus cereus LAB: lactic acid bacteria; PSE: Pseudomonas spp; YEA: yeast; EC: Escherichia coli.

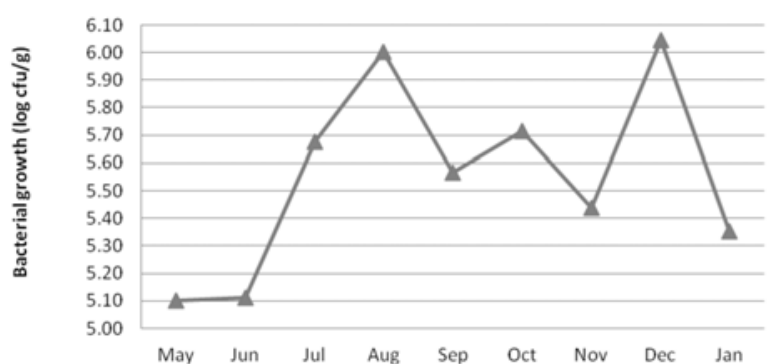

Figure 2. Seasonal trend in the mean mesophilic total content; the data are expressed in logarithmic base. 
monocytogenes (L. monocytogenes) (AFNOR BRD 07/10-04/05); Escherichia coli O157 : H7 (UNI EN ISO 16654: 2003); Total Aerobic Mesophilic Counts (MTC) (AFNOR BIO 12/15-09/05); Enterobacteriaceae (ETB) (AFNOR BIO 12/21-12/06); E. coli (AFNOR BIO 12/13-02/05); Staphylococci (AFNOR BIO 12/28-04/10); B. cereus (ISO 7932:2005); Lactic Acid Bacteria (LAB) (ISO15214:1998); Pseudomonas spp. (ISO/TS 11059IDF/RM 225 01-08-2009); yeast and molds (ISO 21527-1: 2008). Both $\mathrm{pH}$ (Five Easy Plus Metter-ToledoAG) and $\mathrm{a}_{\mathrm{w}}$ (AQUA LAB- Dewpoint water activity meter) were also monitored on each occasion.

\section{Results}

The results obtained are reported in Figure 1 and in Table 1. The following average values were recorded in the analyzed samples: E. coli $3.07 \mathrm{log} \mathrm{cfu} / \mathrm{g}$; Staphylococci $1.30 \quad \log \mathrm{cfu} / \mathrm{g}$; Total Mesophilic Counts $6.12 \log \mathrm{cfu} / \mathrm{g}$; Enterobacteriaceae 4.79 log cfu/g; Pseudomonas spp. $6.86 \mathrm{log} \mathrm{cfu} / \mathrm{g}$; B. cereus $2.72 \log$ cfu g; yeasts and molds $3.90 \mathrm{log}$ $\mathrm{cfu} / \mathrm{g}$ and lactic acid bacteria $4.61 \mathrm{log} \mathrm{cfu} / \mathrm{g}$. (Figure 1). The presence of Salmonella spp. and L. monocytogenes was never detected. At the organoleptic analysis no change in color, smell or texture was observed. The $\mathrm{pH}$ and $\mathrm{a}_{\mathrm{w}}$ values were stable, ranging from 6.2 to 6.7 and from 0.987 to 1.00 , respectively.

\section{Discussion and Conclusions}

The monitoring carried out represents a starting point for the evaluation of a traditional Italian product, which has at the moment a mainly local distribution. The data obtained from the examined samples demonstrate a high level of Total Mesophilic Counts during the whole period, with peaks occurring in August (6.00 log cfu/g) and December (5.60 log cfu/g) (Figure 2).

The higher microbial concentrations

Table 1. Average values of $\mathrm{pH}$ and water activity May 2014-Jan 2015.

\begin{tabular}{cccccccccc} 
& May & Jun & Jul & Aug & Sep & Oct & Nov & Dec & Jan \\
$\mathrm{pH}$ & 6.47 & 6.38 & 6.42 & 6.53 & 6.65 & 6.57 & 6.26 & 6.32 & 6.53 \\
$\mathrm{~A}_{\mathrm{W}}$ & 1.000 & 1.000 & 0.998 & 0.998 & 0.998 & 0.990 & 0.992 & 0.991 & 0.987 \\
\hline
\end{tabular}

found in the months of increased commercial activity stress the need of a better control of the supply chain in all production seasons. Three of the dairies selected were located in old premises that seemed unsuitable to prevent the cross-contamination in the different stages of production and the postcontamination of the finished product in the later stages. The best microbiological results were obtained in the samples of the fourth dairy where a better control of the hygiene process and a satisfactory adequacy of the premises were observed. It is well known that food may be contaminated through direct contact with different surfaces of the processing equipment and environment (Greenwood et al., 1991; Kousta et al., 2010). Contamination is frequently caused by microorganisms belonging to the genus Pseudomonas spp., which can persist within niches in the processing environment, if protected by a structured biofilm ecosystem (Simões et al., 2009). In this study, average values of Pseudomonas spp. found in the dairies where the whey was directly poured into the steam boilers ( $7.07 \mathrm{log} \mathrm{cfu} / \mathrm{g}$ ) were higher than those of the dairies with doublebottomed boilers (6.43 log $\mathrm{cfu} / \mathrm{g})$. Considering the high temperatures of steam inflation in whey there is not a real risk of contamination by the biofilm that may form in the pipes of boilers. Nevertheless, the fact that a high concentration of Pseudomonas spp. adversely affects the taste and texture of the product (Leriche et al., 2004) should not be underestimated to guarantee the quality of the ricotta. The climatic and geographical conditions of the production areas greatly contribute to the typical taste and flavour of the Campania buffalo ricotta cheese. The properties of the milk are transferred to ricotta by using only sweet whey from the breakage of fresh buffalo milk clot (EC Reg. 510/2006; European Commission, 2006). Standardization of the procedures, adequacy of the premises, corrective actions, staff reliabity and training are important conditions to improve and preserve the quality and safety of the product.

\section{References}

Addeo F, Coppola S, Pelissier JP, Chianese L, 1983. Primary structure of water buffalo $\mathrm{f} 3$ casein tryptic and $\mathrm{CNBr}$ peptides. J Dairy Res 47:421-6.

De Santis EPL, Mazzette R, Scintu MF, Deriu A, Carta A, 1999. Prove di produzione industriale della ricotta ovina confezionata: evoluzione dei parametri microbiologici nel corso della conservazione. A.I.V.I. 1999:183-8.

European Commission, 2006. Council Regulation (EC) N. 510/2006, publication of an application pursuant to Article 6(2) on the protection of geographical indications and designations of origin for agricultural products and foodstuffs. European Commission, Bruxelles, Belgium.

Greenwood MH, Roberts D, Burden P, 1991. The occurrence of Listeria species in milk and dairy products: a national survey in England and Wales. Int $\mathrm{J}$ Food Microbiol 12:197-206.

Kousta M, Mataragas M, Skandamis P, Drosinos EH, 2010. Prevalence and sources of cheese contamination with pathogens at farm and processing levels. Food Control 21:805-15.

Leriche F, Bordessoulesb A, Fayollea K, Karoui R, Lavalb K, Leblanca L, Dufour E, 2004. Alteration of raw-milk cheese by Pseudomonas spp.: monitoring the sources of contamination using fluorescence spectroscopy and metabolic profiling. J Microbiol Meth 59:3341.

Mucchetti G, Neviani E, 2006. Microbiologia e tecnologia lattiero casearia. Tecniche Nuove, Milan, Italy.

Simões M, Simões LC, Vieira MJ, 2009. Species association increases biofilm resistance to chemical and mechanical treatments. Water Res 43:229-37. 